\title{
Different type of matrix for cardiac implants: biomedical and bioengineering aspects
}

\author{
Shchotkina N. ${ }^{1,2,3}$, Sokol A. ${ }^{1}$, Dolinchuk L. ${ }^{2}$, Skorohod I. ${ }^{3}$, Filipov R. ${ }^{2}$, Shepeleva O. ${ }^{2}$, Rudenko N. ${ }^{1}$, Yemets I. ${ }^{1}$ \\ ${ }^{1}$ Ukrainian Children's Cardiac Center, Kyiv, Ukraine \\ ${ }^{2}$ Igor Sikorsky Kyiv Polytechnic Institute, National Technical University of Ukraine, Kyiv, Ukraine \\ ${ }^{3}$ Xpand LLC, Kyiv, Ukraine
}

Corresponding author’s e-mail: cardiotissue@gmail.com

\section{ABSTRACT}

The rapid growth of cardiovascular morbidity and high mortality rates of patients with congenital heart disease requiring surgery have led to the search for new modern approaches to the treatment of these groups of patients. The main trends today include the use of cardiac implants of synthetic and biological origin. Of particular interest are scaffolds based on the decellularized extracellular matrix, which in its functional and structural characteristics is close to the native pericardium. In contrast to synthetic analogues, such grafts can fully replace tissue or organ defects defects, and then integrate and function properly.

This review presents the characteristics of different types of matrices used in cardiac surgery. The advantages and disadvantages of commercially available cardiac bioimplants currently used in the world are analyzed.

KEY WORDS: tissue engineering; cardiac bioimplant; extracellular matrix

Modern regenerative medicine successfully combines data from basic research and clinical practice, which provides great potential for therapeutic use. It is based on the restoration or replacement of tissues and organs that have a structural or functional deficiency, due to synthetic, biological and extracellular matrices [1]. Synthetic scaffolds provide the ability to modify and control the structural properties, but do not guarantee the same functionality as native tissue [2]. The advantage of using biomaterials in tissue engineering is due to their ability to be resorbed in the body with subsequent replacement by recipient's tissues. However, scaffolds based on natural extracellular matrix (ECM), reproducing the microarchitectonics of native tissue, are of increasing interest [3].

The PURPOSE of this review was to analyze modern approaches and trends in obtaining and application of different types of matrix scaffolds for cardiac implants, including biomedical and bioengineering aspects.

\section{CLASSIFICATION AND CHARACTERISTIC OF DIFFERENT TYPES}

OF MATRIX SCAFFOLDS FOR CARDIAC IMPLANTS

One of the most difficult problems of modern tissue engineering is the choice of a scaffold for the engraftment of cells in vitro and in vivo, which is an important aspect in the implant transplantation into the human body. The main functions of the matrix are the providing of intercellular connections, control of tissue structure and regulation of cell phenotype [4]. Matrices made of biomaterials regulate cell density and production of biologically active factors; determine three-dimensional structure of tissue and formation of new tissue $[5,6]$.

All the variety of matrices can be divided into three major groups:

1. Synthetic polymers.

2. Natural.

3. Extracellular matrix.

The main advantages of the first two groups are their natural origin and easier integration into the recipient's tissue. However, unlike synthetic polymers, it is almost impossible to control the microstructure of such substances. At the same time, natural biomaterials provide the same matrix architecture as the native tissue.

In cardiac surgery, synthetic polymers approved by the Food and Drug Administration (FDA) are used to create resorbable sutures [7]. Synthetic materials are mostly thermoplastic and can take any shape, which is important in the production of cell matrices with a certain pore diameter.

One of the known natural biomaterials for creating cellular scaffolds is collagen. The plasticity, low toxicity and antigenicity of the biomaterial and at the same time its high mechanical strength provide advantages for the widespread use of collagen in surgery [6].

Polysaccharide of plant origin, such as an extract from seaweed - alginate - is used to create jelly-like matrices with a high content of calcium ions $[5,8,9]$. Alginate has found application for the treatment of open wounds. However, the structural and functional properties of alginate are 
limited by the length of the polysaccharide chains, which limits its widespread use [5].

Extracellular pericardial matrix is created by removing cells and their components from the native pericardial tissue using chemical, physical and biochemical methods $[3,10]$. In terms of its biomechanical properties, the extracellular matrix differs little from the native pericardial tissue and is, therefore, suitable for the use in the replacement of heart valves and congenital heart defects $[11,12]$.

Most of the currently known bioimplants used in tissue engineering are resorbable and replaced by recipient's tissues. The material must meet the following requirements: the absence of toxic products, it should not change the $\mathrm{pH}$ of the tissue or inhibit the growth and differentiation of cells. Non-resorbable materials are practically not used today (except for bone prostheses, although the use of metal implants is being reduced due to their ability to corrode in aggressive tissue environments), as they limit regenerative potential and can cause excessive connective tissue growth, and sometimes provoke an immune response to foreign bodies [10-13].

From the perspective of biomechanics, the functional materials for implantation in the body should be similar to tissues, i.e. be characterized by elasticity and have a stress-strain curve close to tissues and specific loading-unloading hysteresis loop [11].

\section{SYNTHETIC MATRICES}

Synthetic polymers due to its properties (light, flexible, elastic, strong) are well suitable for the application in cardiac surgery. Today, polyethylene, polypropylene, silicone, polytetrafluoroethylene (Teflon ${ }^{\circledR}$, polyethylene terephthalate $\left(\right.$ Dacron $\left.^{\circledR}\right)$, polymethyl methacrylate, polyurethane, some types of resins, etc. are used to create heart valves and blood vessels. However, in the long term after implantation there is a degradation of polymer compounds, which determines the main disadvantage of this group of substances. In an aggressive tissue environment, implants are attacked by the cells of the immune system that have a lot of oxidizing and hydrolyzing substances. Also, the presence of oxidizing free radicals, such as peroxides, lipids, lipoproteins, etc., adversely affects the structure of synthetic polymers, while reducing their strength. The degradation of the prosthesis is accompanied by monomers cleavage from the long chain. Theoretically, these monomers can enter blood, lymph and cause toxic effects, changes in tissue pH. Also, the lack of biocompatible and biological signals in these polymers is of serious concern [14]. Synthetic scaffolds lack the spatial organization that can be observed in natural extracellular matrices. However, their great advantage is that they can be easily modified, change a wide range of mechanical and chemical properties, including the degradation rate.

For the correction of some congenital heart defects in children and the replacement of the pulmonary valve, which is used for aortic valve prosthesis, prostheses made of porous polytetrafluoroethylene composite are widely used. They are biologically and chemically inert, resistant to aggressive body fluids and bacterial agents. It is important to note that polytetrafluoroethylene can be used to build arterial shunts in newborns with complex cyanotic heart disease, for the palliative reconstruction of the interrupted aortic arch, the construction of an extra-anatomic aortic bypass graft and total cavopulmonary connection. It is also suitable for the septal defects closure, the plastic reconstruction of the right and left ventricular outflow tracts, as well as the correction of aortic coarctation and the plastic repair of stenosis in the pulmonary artery and its branches. Polytetrafluoroethylene patches can be used for the plastic reconstruction of atrioventricular valves [15-18].

Porous polytetrafluoroethylene has been successfully tested for the manufacture of artificial prostheses for cardiac surgery in the clinical practice of the State "Scientific and Practical Medical Center for Pediatric Cardiology and Cardiac Surgery of the Ministry of Health of Ukraine". In comparison with prototypes, this synthetic polymer has the following advantages: the high level of biocompatibility; no cytotoxic effects; necessary biomechanical properties; low microbial adhesion; the low rate of postoperative complications.
The closest analogue of this polymer is polyethylene terephthalate (trade names Dacron ${ }^{\circledR}$, Gore-Tex Surgical Membrane, Mylar). This is a thermoplastic used to create artificial prostheses with high mechanical performance. However, its use has a number of disadvantages, i.e. cytotoxicity. Also, compared to other synthetic substances, polyethylene terephthalate was associated with a higher risk of stroke, transient ischemic attack and carotid artery thrombosis in the postoperative period [19].

\section{NATURAL MATRICES}

Collagen. Type I collagen is most often used as a scaffold in tissue engineering, because it is the major protein of the extracellular matrix of many native tissues and provides most of the mechanical and tensile strength. In addition, collagen has low antigenicity, weak immunogenicity and is biodegradable [7]. The use of collagen of animal origin raises concerns about the possible transmission of infectious agents such as prions. An innovative promising alternative strategy is the synthesis of supramolecules based on peptides that imitate the structure and function of collagen [20].

In cardiac surgery, the lyophilized collagen delivery system of gentamicin Collatamp ${ }^{\circledR}$ G (EUSA Pharma, UK) is used in the prevention and treatment of postoperative complications [21]. The implant is based on bovine collagen, which is rapidly degradable and is an effective for local delivery of antibiotics. The advantage is that such implants are degraded by collagenases and do not require surgical removal. At the same time, they provide a high dose of antibiotic in the damaged area, thereby accelerating wound healing [21].

Fibrin. Fibrin gels have controlled characteristics of biodegradability and polymerization. An additional advantage is the fact that they are obtained from the patient's blood allowing to obtain an autologous matrix, which does not emit toxic products or cause inflammatory or immune reactions. In addition, fibrin interacts with tissue and may promote cell proliferation and migration [22]. Elastin-like recombinant fibrin hydrogels were synthesized for the manufacture of heart valves by a seamless method in a modular form with the required geometry of heart valves. This approach will also allow you to create multilayer structures $[23,24]$.

Hydrogels. Hydrogels are three-dimensional scaffolds made of highly hydrophilic polymers, which allows them to contain a certain amount of water. Depending on the topology, structure and chemical composition of polymer scaffolds, the mechanical properties of such hydrogels range from brittle with low fracture energy $\left(10-100 \mathrm{~J} / \mathrm{m}^{2}\right)$ to extremely rigid with fracture energy $\left(\sim 100-10000 \mathrm{~J} / \mathrm{m}^{2}\right)[25]$

Hydrogels based on hyaluronic acid are increasingly used to create tissue-engineered matrices of heart valves, because hyaluronic acid is a unique type of glycosaminoglycans that exists in free form without a covalently bound protein. Hyaluronic acid plays an important role in biological processes, such as the construction of tissue structures, cell migration and differentiation. Such hydrogels significantly increase the production of the extracellular matrix by the inner cells of the valve, and the products of degradation of the hydrogel increase the proliferation of the intercellular matrix of the valve [26]. Elastin synthesis is also induced when cells are seeded on such a hydrogel; as a result, elastin scaffold is similar to the matrix of a native aortic valve [27].

The components of the collagen-chondroitin sulfate hydrogel type I were also studied [28]. When seeded on chondroitin sulfate hydrogel, the porosity of the matrix increases, biological activity of cells and matrix remodeling improve. Increased gel engraftment by endothelial cells and increased extracellular matrix production, including fibronectin, laminin, collagen and elastin, have also been demonstrated. Thus, many hydrogel systems used in cardiovascular surgery act as biocompatible scaffolds to support cells [29, 30].

Silk fibroin. Scaffolds based on fibrillar protein fibroin derived from Bombyx mori are increasingly used for tissue engineering of vascular endothelium [31]. The material has unique biophysical and biochemical properties that determine its reliability, flexibility, biocompatibility, ability to biodegrade [32]. To create implants, the technique of electrospinning 


\begin{tabular}{|c|c|c|c|}
\hline $\begin{array}{l}\text { PRODUCT NAME, MANUFACTURER/ } \\
\text { DEVELOPER }\end{array}$ & $\begin{array}{l}\text { TYPE OF XENOGENEIC } \\
\text { TISSUE }\end{array}$ & PROCESSING METHOD & REFERENCE \\
\hline $\begin{array}{l}\text { Bovine Pericardium Patch } \\
\text { (Braile Biomedica, São José do Rio Preto, Brazil) }\end{array}$ & Bovine pericardium & Glutaraldehyde & [43] \\
\hline $\begin{array}{l}\text { Edwards Bovine Pericardial } \\
\text { (Edwards Lifesciences, Irvine, CA, USA) }\end{array}$ & Bovine pericardium & $\begin{array}{l}\text { GA-cross-linking, patented anti-calcification } \\
\text { treatment }\end{array}$ & [44] \\
\hline $\begin{array}{l}\text { PhotoFix } \\
\text { (CryoLife, Kennesaw, GA, USA) }\end{array}$ & Bovine pericardium & Decellularization and photooxidation & [45] \\
\hline $\begin{array}{l}\text { SURGIFOC } \\
\text { (FOC Medical, Buenos Aires, Argentina) }\end{array}$ & $\begin{array}{l}\text { Pig pericardium / } \\
\text { Bovine pericardium }\end{array}$ & GA-cross-linking & [46] \\
\hline CardioCel (Admedus, Malaga, Western Australia) & Bovine pericardium & $\begin{array}{l}\text { GA-cross-linking, decellularization and } \\
\text { processing by a patented technique }\end{array}$ & [47] \\
\hline $\begin{array}{l}\text { Matrix Patch } \\
\text { (Auto Tissue Berlin, Germany) }\end{array}$ & Horse pericardium & Decellularization & [29] \\
\hline $\begin{array}{l}\text { No-React (Biolntegral Surgical } \\
\text { Mississauga, Ontario, Canada) }\end{array}$ & Pig pericardium & Heparin treatment & [48] \\
\hline $\begin{array}{l}\text { Peri-Guard } \\
\text { (Baxter International Inc. Deerfield, Illinois, USA) }\end{array}$ & Bovine pericardium & GA-cross-linking & [49] \\
\hline Tiflex (Xpand LLC, Ukraine) & Bovine pericardium & $\begin{array}{l}\text { Decellularization with } 0.1 \% \text { sodium dodecyl } \\
\text { sulfate + cross-linking }\end{array}$ & [11] \\
\hline
\end{tabular}

Table 1. Commercially available acellular pericardial scaffolds from xenogeneic tissues.

is used, which allows the production of nano/microfibers of silk fibroin in large number with accurate imitation of the extracellular matrix of the required tissue $[33,34]$. The advantages of the electrospinning technique are the creation of a porous surface that ensures the penetration of oxygen molecules, and the increase of cells adhesion to the implant by increasing the surface area of the matrix. Cells can easily adhere to such structures, multiply and form monolayers of cells with preserved phenotypic characteristics.

Thus, biological/natural matrices have advantages over synthetic scaffolds, because they are capable of intermolecular signaling, promote cell proliferation, differentiation and functioning. However, it is very difficult to control the mechanical properties and the rate of biodegradation of such implants. Natural materials can also provoke an undesirable immune response.

\section{EXTRACELLULAR MATRIX}

Biomaterials used in tissue engineering and regenerative medicine try to reproduce the multifactorial aspects of the extracellular matrix (ECM) function. However, synthetic materials and matrices formed from biological materials, such as collagen, fibrin or hyaluronic acid, cannot achieve molecular and spatial organization of native tissue. This promoted the use of natural ECM as a source of scaffold.

In order to obtain biomaterial that is structurally and functionally close to tissues or organs and at the same time is immunologically safe, a technology of decellularization of tissues and organs from humans and animals for clinical application of ECM has been proposed. This technology uses physical, chemical and/or biochemical methods to remove cellular antigens from native tissue or organ of xenogeneic or allogeneic origin. This process is aimed at ensuring immunological safety and preserving the architecture of the matrix, which includes protein, collagen and glycosamines. The final product is a three-dimensional ECM scaffold which is similar to the native tissue [3]. To date, some organs and tissues have been successfully decellularized, including heart valves, myocardium, pericardium, blood vessels, lungs, pancreas, kidneys, liver, mammary gland, and nerves [10]. Decellularized xenogeneic scaffolds have been successfully used in the clinic for tissue engineering and regenerative medicine [35]

One of the most common materials for xenoplasty is the decellularized bovine pericardium, which is widely used in cardiac surgery to re- place heart valves and treat congenital heart defects [11]. The structure of xenogeneic tissues is rich in elastic and collagen fibers, which gives the pericardium increased resistance to mechanical load. The formation of a straight suture line in cardiovascular surgery is also an important advantage of using a decellularized bovine pericardium [36, 37]. To reduce the immune response and graft rejection, the pericardium is fixed in glutaraldehyde. However, its incomplete removal can lead to cytotoxicity and late calcification of the implant in vivo [38]. That led to the search and development of new methods for the production of safe heart implants. One of the most common techniques is to treat the tissue with ionic detergents such as sodium dodecyl sulfate. However, its use in high concentrations can lead to structural disorders of ECM and have a cytotoxic effect on human cells [39]. At the same time, there are convincing data on the safety of sodium dodecyl sulfate in low concentrations $(0.1 \%)$.

Table 1 presents commercially available decellularized scaffolds for cardiac surgery, manufactured by various methods. Such type of product is mostly represented in Europe and America. Manufacturers prefer the use of xenogeneic tissues based on the pericardium of pigs, cattle and horses. A cardiac implant made from bovine pericardium has a number of technical advantages such as easy application, necessary biomechanical properties, biocompatibility, less bleeding from the sutures and the possibility of immediate arterial duplex ultrasound at the angioplasty site [40]. The extracellular matrix of the bovine pericardium is cell-free and contains pure collagen. Thus, it can provide natural transport of micronutrients and proliferation of recipient cells, accelerating endothelialization and tissue regeneration [41]. Comparison of bovine pericardium with other materials, such as polytetrafluoroethylene, to close ventricular septal defects, did not show significant differences in results [42]. However, surgeons prefer bovine pericardium because of its elasticity and lower risk of postoperative endocarditis. Some manufacturers claim that their implants have anti-calcification technology that can significantly reduce calcification and support endothelialization $[44,49]$.

The testing of a unique method of bovine pericardium decellularization was started in the State "Scientific and Practical Medical Center of Pediatric Cardiology and Cardiac Surgery" of the Ministry of Health of Ukraine. It has already successfully passed the stage of preclinical study, which in the long run allows the certification of domestically produced cardiac implants [50, 51]. 


\section{CONCLUSION}

According to the analytical review, it was determined that today a large number of biocompatible materials are used to create cardiac implants, but none of them is ideal. Therefore, the search for new materials for cardiovascular tissue plastics is relevant at the current stage of tissue engineering development. Three groups of matrices (synthetic, natural, extracellular matrix), which are currently used to create cardiac implants, have been identified. The main advantages of matrices of biological origin are the providing of molecular intercellular signaling, improved cell proliferation and differentiation in the post-transplant period, which promotes the biointegration of the implant. Synthetic matrices are at the same time standardized with certain mechanical properties and the rate of biodegradation, which contributes to the controlled management of postoperative treatment. An important disadvantage of natural implants is the possibility of developing an immune response to their components.

An increasing preference is given to natural matrices, in particular extracellular matrix based on bovine pericardium, which has advantages over synthetic analogues. The ECM of xenogeneic tissues is the most promising in use for cardiac implants due to its high biocompatibility and integration into the recipient's body.

\section{REFERENCES:}

1. Hacker MC, Krieghoff J, Mikos AG. Synthetic Polymers. In: Atala A, editor. Principles of Regenerative Medicine. 3 ed. Academic Press. 2018:1428-1428.

2. Hench LL, Polak JM. Third-Generation Biomedical Materials. Science. 2002; 295(5557):1014-1017.

3. Gilbert TW, Sellaro TL, Badylak SF. Decellularization of tissues and organs. Biomaterials. 2006; 27(19):3675-3683.

4. Taylor PM, Cass AEG, Yacoub MH Extracellular matrix scaffolds for tissue engineering heart valves. Prog Paediatr Cardiol. 2006a; 21:219-225. D0l:10.1016/j. ppedcard.2005.11.010

5. Chlupac J, Filova E, Havlikova J, et. al. The gene expression of human endothelial cells is modulated by subendothelial extracellular matrix proteins: short-term response to laminar shear stress. Tissue Eng Part A. 2014; 20(15-16):2253-64. D0I: 10.1089/ten.TEA.2013.0153

6. d'Ayala GG, Malinconico M, Laurienzo P. Marine derived polysaccharides for biomedical applications: chemical modification approaches. Molecules. 2008; 13:2069-2106. DOI:10.3390/molecules13092069

7. Chevallay $B$, Herbage $D$. Collagen-based biomaterials as 3D scaffold for cell cultures: applications for tissue engineering and gene therapy. Med Biol Eng Comput. 2000; 38:211-218. DOI:10.1007/BF02344779

8. Chung-Welch N, Patton WF, Yen-Patton GP, et. al. Phenotypic comparison between mesothelial and microvascular endothelial cell lineages using conventional endothelial cell markers, cytoskeletal protein markers and in vitro assays of angiogenic potential. Differentiation. 1989; 42(1):44-53. DOl: 10.1111/j.14320436.1989.tb00606.x

9. Fan T, Ma X, Zhao J, et. al. Transplantation of tissue-engineered human corneal endothelium in cat models. Mol Vis. 2013; 19:400-7.

10. Pawan KC, Yi Hong, Ge Zhang. Cardiac tissue-derived extracellular matrix scaffolds for myocardial repair: advantages and challenges. Regen Biomater. 2019; 6(4):185-199. DOl: 10.1093/rb/rbz017

11. Shchotkina NV, Sokol AA, Galkin OYu, et. al. Optimized method of bovine pericardium decellularization for tissue engineering. Wiad Lek. 2021; 74(4):815-820. D0I: 10.36740/WLek202104101

12. Sokol AA, Grekov DA, Yemets Gl, Galkin AYu, et. al. The efficiency of decellularization of bovine pericardium by different concentrations of sodium dodecyl sulfate. Innov Biosyst Bioeng. 2020; 4(4):189-198. DOl: 10.20535/ibb.2020.4.4.214765

13. Sultanova AS, Bespalova OYa, Galkin OYu. Stromal-vascular fraction of adipose tissue as an alternative source of cellular material for regenerative medicine. Ukr Biochem J. 2021; 93(1): 40-50. DOI: 10.15407/ubj93.01.040

14. Wilshaw SP, Kearney JN, Fisher J, et. al. Production of an acellular amniotic membrane matrix for use in tissue engineering. Tissue Eng. 2006; 12(8):2117-29. DOI: 10.1089/ten.2006.12.2117

15. Quintessenza JA, Jacobs JP, Chai PJ, et. al. Polytetrafluoroethylene bicuspid pulmonary valve implantation: experience with 126 patients. World J Pediatr Congenit Heart Surg. 2010; 1:20-27.

16. Quintessenza JA, Jacobs JP, Morell VO, et. al. Initial experience with a bicuspid polytetrafluoroethylene pulmonary valve in 41 children and adults: a new option for right ventricular outflow tract reconstruction. Ann Thorac Surg. 2005; 79:924-931.

17. Choi $\mathrm{KH}$, Sung SC, Kim H, et. al. Late results of right ventricular outflow tract reconstruction with a bicuspid expanded polytetrafluoroethylene valved conduit. J Card Surg. 2018; 33:36-40.

18. Grigorieva SM, Starosyla DB, Rybalko SL, et. al. Effect of recombinant human interleukin-7 on Pseudomonas aeruginosa wound infection. Ukr Biochem J. 2019; 91(5):7-15. DOl: 10.15407/ubj91.05.007

19. Perkasem K, Rothwell PM. Patches of different types for carotid patch angioplasty. Cochrane Database of Systematic Reviews 2010. D0I:10.1002/14651858. CD000071.pub3.

20. Klopsch C, Steinhoff G. Tissue-engineered devices in cardiovascular surgery. Eur Surg Res. 2012; 49(1):44-52. D0I: 10.1159/000339606

21. Mishra PK, Ashoub A, Salhiyyah K. Role of topical application of gentamicin containing collagen implants in cardiac surgery. J Cardiothorac Surg. $2014 ; \mathbf{9} 9: 122$. DOI: 10.1186/1749-8090-9-122.

22. Weber M, Gonzalez de Torre, Moreira R, et. al. Multiple-Step Injection Molding for Fibrin-Based Tissue-Engineered Heart Valves. Tissue Eng Part C Methods. 2015; 21(8):832-840. DOI: 10.1089/ten.tec.2014.0396

23. Miriam W, Israel GdT, Ricardo M, et. al. Multiple-step injection molding for fibrin-based tissue-engineered heart valves. Tissue Eng. Part C. 2015; 21:832-840.

24. Galkin OYu, Komar AG, Besarab OB. Different mice inbred strains humoral immune response against human prostate-specific antigen. Ukr Biochem J. 2019; 91(1): 30-37. DOl: 10.15407/ubj91.01.030

25. Naficy S, Brown HR, Razal JM, et. al. Progress toward robust polymer hydrogels. Aust J Chem. 2011; 64:1007-1025.

26. Taylor PM. Biological matrices and bionanotechnology. Philos Trans R Soc Lond B Biol Sci. 2007; 362(1484):1313-1320. D0l:10.1098/rstb.2007.2117

27. Tsai SH, Liu YW, Tang WC, et. al. Characterization of porcine arterial endothelial cells cultured on amniotic membrane, a potential matrix for vascular tissue engineering. Biochem Biophys Res Commun. 2007; 357(4):984-90. DOI: 10.1016/j.bbrc.2007.04.047 
28. Vesely I, Ramamurthi A. Evaluation of the matrix-synthesis potential of crosslinked hyaluronan gels for tissue engineering of aortic heart valves. Biomaterials. 2005; 26:999-1010. DOI: 10.1016/j.biomaterials.2004.04.016

29. Lam NT, Lam H, Sturdivant NM, Balachandran K. Fabrication of a matrigel-collagen semi-interpenetrating scaffold for use in dynamic valve interstitial cell culture. Biomed Mater. 2017; 12(4):045013. DOI: 10.1088/1748-605X/aa71be

30. Rhee S, Puetzer JL, Mason BN, et. al. 3D bioprinting of spatially heterogeneous collagen constructs for cartilage tissue engineering. ACS Biomater Sci Eng. 2016; 2:1800-1805.

31. Lim LS, Poh RW, Riau AK, et. al. Biological and ultrastructural properties of acelagraft, a freeze-dried $\gamma$-irradiated human amniotic membrane. Arch Ophthalmol. 2010; 128(10):1303-10. DOI: 10.1001/archophthalmol.2010.222

32. Chen L, Zhu Y, Li Y, et. al. Progress and prospect of electrospun silk fibroin in construction of tissue-engineering scaffold. Sheng Wu Gong Cheng Xue Bao. 2011; 27(6):831-7.

33. Yetkin G, Uludag M, Citgez B, et. al. Prevention of peritoneal adhesions by intraperitoneal administration of vitamin E and human amniotic membrane. Int J Surg. 2009; 7(6):561-5. DOI: 10.1016/j.ijsu.2009.09.007

34. Nastenko leA, Maksymenko VB, Potashev SV, et. al. Random forest algorithm construction for the diagnosis of coronary heart diseasebased on echocardiography video data streams. Innov Biosyst Bioeng. 2021; 5(1): 61-69. DOI: 10.20535/ibb.2021.5.1.225794

35. Jaganathan SK, Supriyanto E, Murugesan S, et. al. Biomaterials in cardiovascular research: applications and clinical implications. Biomed Res Int. 2014; 2014:459465. DOI: 10.1155/2014/459465

36. Lima Ed, Ferrasi AC, Kaasi A. Decellularization of Human Pericardium with Potential Application in Regenerative Medicine. Arq Bras Cardiol. 2019; 113(1):18-19. DOI: $10.5935 / a b c .20190130$

37. Lutsenko TN, Kovalenko MV, Galkin OYu. Validation of biological activity testing procedure of recombinant human interleukin-7. Ukr Biochem J. 2017; 89(1): 8289. DOI: $10.15407 /$ ubj89.01.082

38. Ma B, Wang X, Wu C, Chang J. Crosslinking strategies for preparation of extracellular matrix-derived cardiovascular scaffolds. Regen Biomater. 2014; 1(1):81-89.

39. Gratzer PF, Harrison RD, Woods $T$. Matrix alteration and not residual sodium dodecyl sulfate cytotoxicity affects the cellular repopulation of a decellularized matrix. Tissue Eng. 2006;12(10):2975-83. DOI: 10.1089/ten.2006.12.2975

40. Obermiller JF, Hodde JP, McAlexander CS, et. al. A comparison of suture retention strengths of three biomaterials. Med Sci Monit. 2004 ; 10(1):I1-5.

41. Kim GE, Kwon TW, Cho YP, et. al. Carotid endarterectomy with bovine patch angioplasty: a preliminary report. Cardiovasc Surg. 2001; 9(5):458-62. DOI: 10.1016/ s0967-2109(01)00042-4

42. Us MH, Sungun $M$, Sanioglu S, et. al. A retrospective comparison of bovine pericardium and polytetrafluoroethylene patch for closure of ventricular septal defects. J Int Med Res. 2004; 32(2):218-21. DOI: 10.1177/147323000403200216

43. Gomes WJ, Leal JC, Jatene FB, et. al. Experimental Study and Early Clinical Application Of a Sutureless Aortic Bioprosthesis. Case Reports Braz J Cardiovasc Surg. 2015; 30(5):515-9. DOI: 10.5935/1678-9741.20150072

44. Holoshitz N, Kavinsky CJ, Hijazi ZM. The Edwards SAPIEN Transcatheter Heart Valve for Calcific Aortic Stenosis: A Review of the Valve, Procedure, and Current Literature Cardiol Ther. 2012; 1(1):6. DOI: 10.1007/s40119-012-0006-8

45. Available from: https://clinicaltrials.gov/ct2/show/NCT03669042

46. Iop L, Palmosi T, Dal Sasso E, Gerosa G. Bioengineered tissue solutions for repair, correction and reconstruction in cardiovascular surgery. J Thorac Dis. 2018; 10(Suppl 20): S2390-S2411. DOI: 10.21037/jtd.2018.04.27

47. Salameh A, Greimann W, Vondrys $D$, et. al. Calcification or not. This is the question. A 1-year study of bovine pericardial vascular patches (CardioCel) in minipigs. Semin Thorac Cardiovasc Surg. 2018; 30(1):54-9. D0I: 10.1053/j.semtcvs.2017.09.013

48. Herijgers $P$, Ozaki $S$, Verbeken $E$, et. al. The No-React anticalcification treatment: a comparison of Biocor No-React II and Toronto SPV stentless bioprostheses implanted in sheep.Semin Thorac Cardiovasc Surg. 1999; 11(4):171-5.

49. De Martino A, Milano AD, Bortolotti U. Use of Pericardium for Cardiac Reconstruction Procedures in Acquired Heart Diseases-A Comprehensive Review. Thorac Cardiovasc Surg. 2021; 69(1):83-91. DOI: 10.1055/s-0039-1697918

50. Sokol AA, Grekov DA, Yemets Gl, et. al. Biocompatibility analysis of the decellularized bovine pericardium. Cell Organ Transpl. 2020; 8(2):112-116. D0I: 10.22494/ cot.v8i2.110

51. Sokol AA, Grekov DA, Yemets Gl, et. al. Comparison of bovine pericardium decellularization protocols for production of biomaterial for cardiac surgery. Biopolym Cell. 2020; 36(5):392-403. DOI: 10.7124/bc.000A3C

\begin{tabular}{|l}
\hline \\
ARTICLE ON THE SITE \\
\hline
\end{tabular}




\section{Різні типи матриксів для кардіоімплантів: біомедичні та біоінженерні аспекти}

Щоткіна Н. В. ${ }^{1,2,3}$, Сокол А. А. ${ }^{1}$, Долінчук Л. В. ${ }^{2}$, Скороход I. М. ${ }^{3}$, Філіпов Р. Ю. ${ }^{2}$,

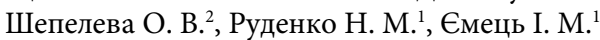

${ }^{1}$ Науково-практичний медччний центр дитячої кардіології та кардіохірургії МОЗ України, Київ, Україна

${ }^{2}$ Національний технічний університет Украйни «Київський політехнічний інститут імені Ігоря Сікорського», Київ, Україна

${ }^{3}$ ТОВ «Ікспанд», Київ, Україна

\section{PE3ЮME}

Стрімкий ріст захворюваності серцево-судинної системи та високі показники смертності пацієнтів із вродженими вадами серця, що потребують хірургічного втручання, обумовили пошук нових сучасних підходів до лікування цих груп пацієнтів. До основних тенденцій сьогодення можна віднести застосування кардіоімплантів синтетичного та біологічного походження. Окремий інтерес викликають трансплантати виготовлені на основі очищеного від клітин та їх компонентів позаклітинного матриксу, що за своїми фрункціональними та структурними характеристиками близький до нативного перикарду. На противагу синтетичних аналогів, такі конструкції можуть повноцінно замінити дефектну частину тканини чи органу, після чого інтегруватися і повноцінно функціонувати.

В даному огляді представленні характеристики різних видів матриксів, що застосовуються в кардіотрансплантології. Проаналізовано переваги та недоліки комерційних біоімплантів, що на сьогодні використовуються в світі.

КЛючовІ СловА: тканинна інженерія; серцевий біоімплант; екстрацелюлярний матрикс 